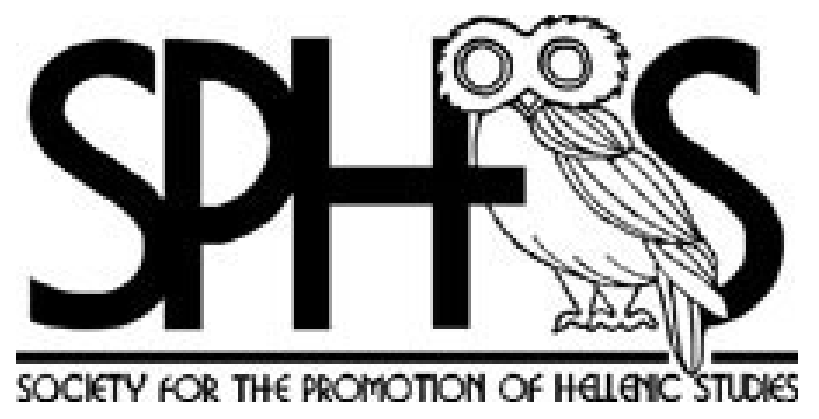

Two Heads Related to the Echoiseul-Gouffier Type

Author(s): Katharine A. McDowall

Source: The Journal of Hellenic Studies, Vol. 24 (1904), pp. 203-207

Published by: The Society for the Promotion of Hellenic Studies

Stable URL: http://www.jstor.org/stable/624028

Accessed: 01/02/2015 10:31

Your use of the JSTOR archive indicates your acceptance of the Terms \& Conditions of Use, available at

http://www.jstor.org/page/info/about/policies/terms.jsp

JSTOR is a not-for-profit service that helps scholars, researchers, and students discover, use, and build upon a wide range of content in a trusted digital archive. We use information technology and tools to increase productivity and facilitate new forms of scholarship. For more information about JSTOR, please contact support@ jstor.org.

The Society for the Promotion of Hellenic Studies is collaborating with JSTOR to digitize, preserve and extend access to The Journal of Hellenic Studies. 


\section{TWO HEADS RELATED TO THE CHOISEUL-GOUFFIER TYPE.}

I. In spite of much discussion, the question of Apollo versus Athlete in this famous group of monuments remains undecided. Though there is. considerable difference in detail, the rendering of the hair as a purely athletic

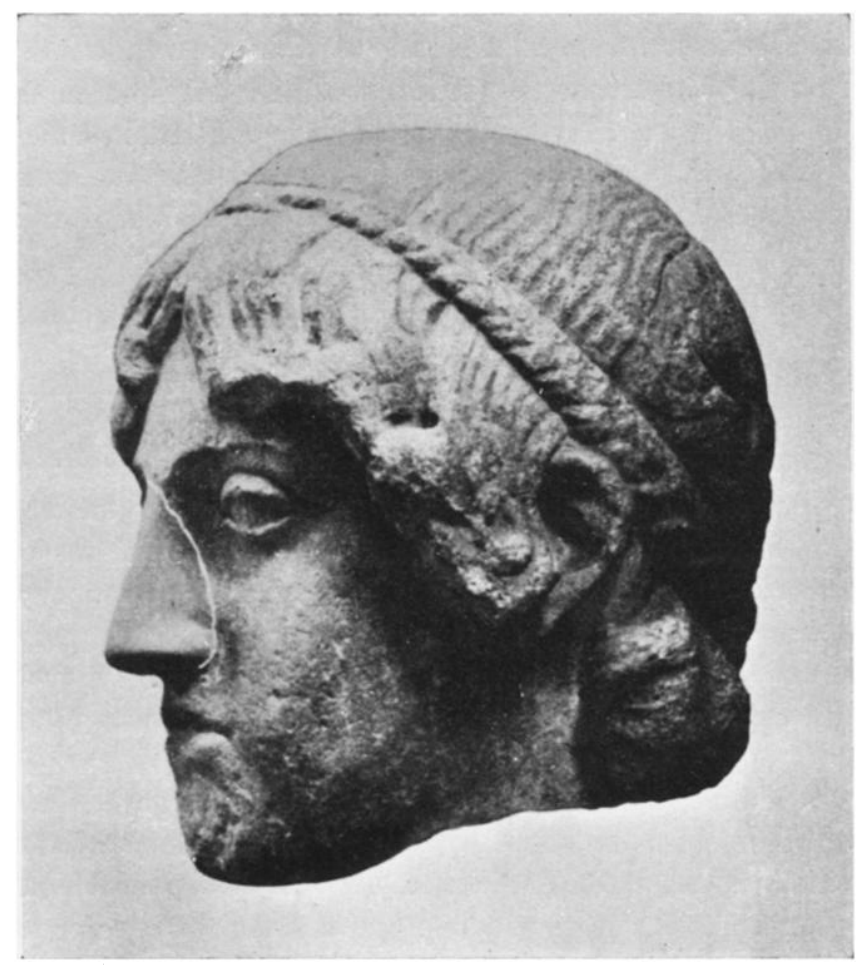

Fig, 1.-Head of Apollo in British Museum.

coiffure is common to all the replicas, ${ }^{1}$ but an additional feature in an unpublished head in the British Museum ${ }^{2}$ seems to have escaped notice, and the

1 The argument for the Apollo attribution, based on the curls round the face, falls to the ground in view of the coiffure of the accumulating ephebe heads of this and a slightly earlier period.
2 I have to thank the late Mr. A. S. Murray for permission to publish this interesting head, and to reproduce on a larger scale than heretofore that which follows. 
light it throws on the subject is such as perhaps to justify a fresh consideration of the evidence.

This head (Fig. 1), whose provenance is uncertain, answer's closely to the other replicas save in one point, the hair. The position and character of the locks about the face are very similar, and it agrees with the majority of examples in the arrangement of the plaits behind, which are carefully worked out, the Choiseul-Gouffier head being quite exceptional in its rendering. Just behind the ear, however, and attached in a thoroughly inorganic fashion, are two large corkscrew curls, ${ }^{3}$ side by side, so entirely unsuitable to the type of head as instantly to suggest an addition, even were the existence of numerous replicas in which they are absent not a proof of this. What has happened is clear. The sculptor adopted a well-known athletic type, and tried to turn it into an Apollo by the use of the ordinary external attributes of the god, hair loose round the face, long curls behind the ear. ${ }^{4}$

The only other instance of an Apolline attribute in replicas of the statue is the quiver on the support in the much modified example in the Palazzo Torlonia. But $(a)$ the statue is a copy of a bronze original, in which a support would be absent, $(b)$ the quiver does not appear elsewhere, and would seem to be another instance of the change of athlete into god visible in the Museum head, ${ }^{5}(c)$ the presence of the quiver does not always indicate a god, as e.y. in the Delos replica of the Diadumenos.

An instance of a similar use of this type of head appears in a statue of Apollo from Olympia, of interest in this connection. The coiffure is precisely the same, and the presence of remains of a lyre render the attribution certain, but it is instructive to find that the excavators do not assign it to the fifth century ${ }^{6}$ but to a much later period. When long hair was no longer the fashion for athletes, it is easy to see how a free creation of later date might come to receive the plaits as genuinely Apolline, though in reality a commonplace of earlier athletic art. This confirms the theory suggested by the Museum head and the Torlonia statne, which illustrate the ways of copyists in dealing with a famous original, and throw fresh light on a much-disputed question.

Finally, I should like to bring forward three arguments not yet, I believe, brought to bear on the controversy as to the attribution of the original to Calamis. First, as Prof. E. A. Gardner has pointed out ${ }^{6 a}$, in the exceptionally long list of statues ascribed to Calamis, ${ }^{7}$ one class, the athlete, is conspicuously absent. This fact, in connection with the use of the words $\chi u ́ p \iota s$ and $\lambda \epsilon \pi \tau o ́ \tau \eta s^{8}$ to characterize his style, should make us hesitate to

3 Those on the right side are missing, but their position is clearly shown by the lines of breakage.

4 The head has suffered considerably, the nose being completely gone (an old restoration is replaced by a cast of that of the ChoiseulGouffier athlete) and the chin broken away.
5 Overbeck, Apollon, p. 109, points out the untrustworthy character of this replica.

${ }^{6}$ Olympia, Bildw. p. 224. Taf. lvii. 3-5.

6a Handbook, i. p. 235.

7 Overbeck, S.Q. 508-526.

8 id. 531. 
assign to him a work of so markedly athletic a character. Secondly, if the attribution to him of the Delphi Charioteer be correct-and it tallies with the literary evidence in every particular-the Choiseul-Gouffier type cannot

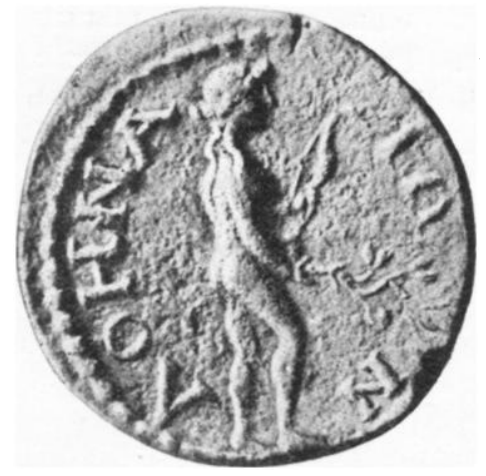

Fig. 2.-Bronze Coin of Athens in the British Museum $(2: 1)$. be the work of the same man, or even of the same school. Thirdly, the type is not identical with the Alexikakos of Calamis reproduced on Attic coins as Furtwängler ${ }^{9}$ suggests. Careful examination of these coins had convinced me of the presence of locks of hair on the shoulders in the true archaic fashion of a cultus statue, and a specimen of the bronze coin in question, recently acquired by the British Museum, decides the matter (Fig. 2). Two long curls hang down behind the ear, while the hair is knotted on the neck and rolled back from the forehead under a fillet in a fashion entirely different from that of the Choiseul-Gouffier type. ${ }^{9 a}$ If then the coins, as is most probable, represent the Alexikakos of Calamis, that statue differed widely from the group of works under discussion, and was of the delicate late archaic character, peculiar to Attic Art of the transitional period, and to Calamis as the representative of that period, a position clearly assigned to him in our literary evidence. ${ }^{10}$

II. In connection with this head I propose to take another (Fig. 3), also in the British Museum, ${ }^{11}$ ably analysed by Mrs. Strong, ${ }^{12}$ who points out its Apolline character. A unique electrum stater of Mytilene ${ }^{13}$ confirms the attribution in a striking manner (Fig. 4). Though somewhat more youthful, and bound by a laurel wreath instead of a fillet in accordance with the usual practice on coins, the resemblance of the squarely built skull with its waving locks to the Museum head is very great. The features too are alike, ${ }^{13 a}$ as are the proportions of the face, both differing widely from the other Apolline heads on coins of Mytilene. It is difficult to believe that the die-cutter had not some such original in his mind when executing this remarkable type, which was issued c. 400 B.c. ${ }^{14}$ That the Museum head is closely related to the Choiseul-Gouffier is certain, and as is the relation between them, so is

\footnotetext{
${ }^{9}$ Apud Roscher, Lexikon, p. 456.

9a $C f$. the famous ephebe head from the Akropolis for the arrangement over the fillet and the knot behind.

${ }^{10}$ A round hole just above the plaits would seem to shew that the Museum head was supported from behind. The statue therefore may have been placed in a niche.
}

11 An inferior replica in Munich. Mtisterwerke, p. 115.

12 Strena Helbigiana, p. 293.

13 B. M. Cat. Troas, etc. Pl. XXXII. 1.

13a In the B.M. head the nose is a restoration.

${ }^{1+}$ Op. cit. Introd. p. lxv. ; text, p. 158. 
that between our coin and a well-known class of Syracusan tetradrachms probably, as Furtwängler suggests, ${ }^{15}$ reflecting the style of Pythagoras, certainly connected with the Choiseul-Gouffier type. Our Apollo and the coin of Mytilene are later in style ${ }^{16}$ but clearly belong to the same school as the Choiseul-Gouffier figure and the tetradrachms, which a plausible conjecture assigns to Pythagoras of Rhegium. Pythagoras was a Samian by birth, and it seems no far-fetched hypothesis that an artist belonging by race to Samos, by adoption to Sicily, by his athletic works to Greece proper, ${ }^{17}$

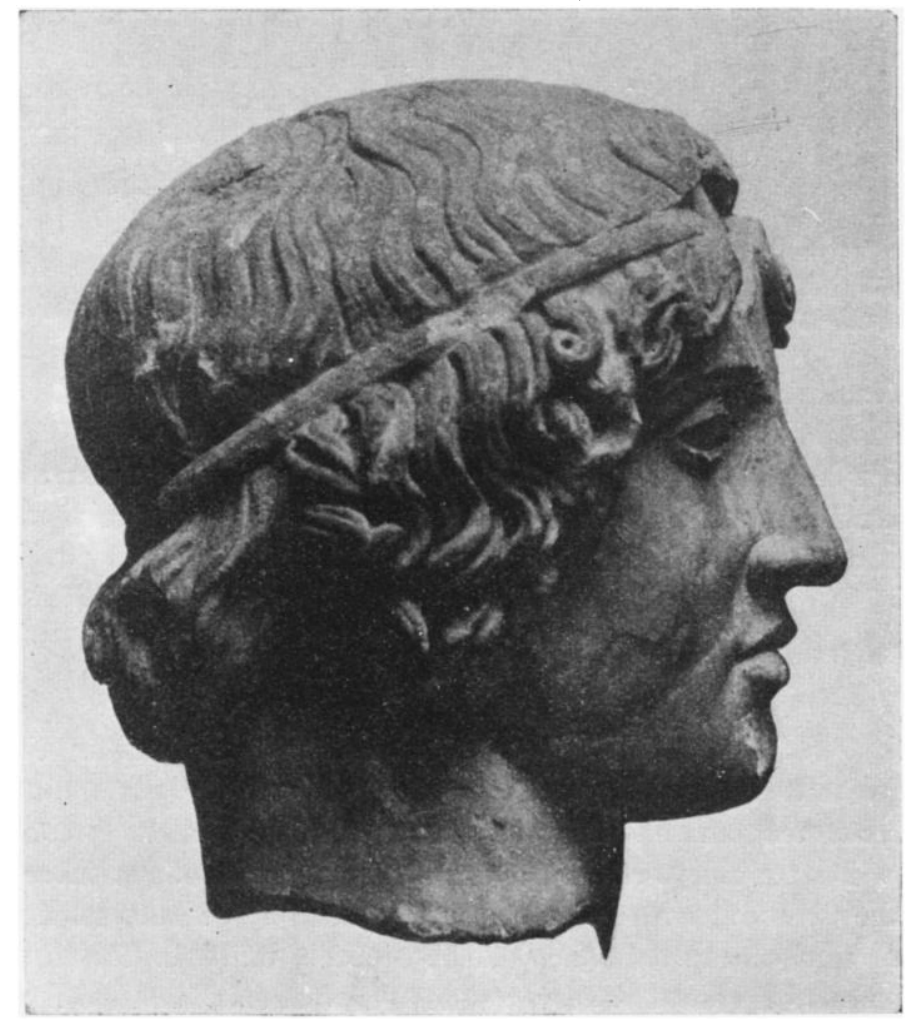

Fig. 3.-Head in the British Meseun.

might be known in the Eastern Mediterranean as in Sicily and the mainland. ${ }^{18}$ It is true that we have no literary evidence for such works, but statues by his purely Attic contemporary Calamis stood in Sicily ${ }^{19}$ and on the borders of the Black Sea, ${ }^{20}$ so that even withont the witness of the coin we might conclude that works of the school of Pythagoras were to be seen in

15 Masterpieces, p. 108 and P1. VI. 14.

16 Notably in the plastic treatment of the hair.

17 Works of his stood in Delphi, Olympia, and Thebes.
18 Replicas of the Choiseul-Gouffier type have been found in Europe, Asia, and Africa.

19 Paus. v. 25.

20 Strabo, vii. 319. 
the islands. The Mytilene type thus confirms the attribution of the head to Apollo instead of Iacchos, the interpretation proposed by Furtwängler, and both are derived from a later work of the school that produced the ChoiseulGouffier figure and kindred works. The differences between them are as

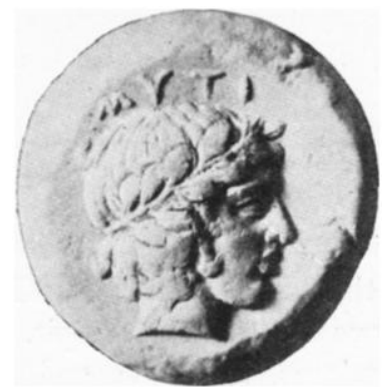

Fig. 4.-Stater of Mrtilene in the British Museum $(2: 1)$.

important as the points of likeness, proving with what care and delicacy the sculptors of this school distinguished between Apollo and Athlete, and giving us examples, confirmed by numismatic evidence, of either type. ${ }^{21}$

Katharine A. McDowall.

21 Mrs. Strong's position (Strexa, loc. cit.) that both are Apollos seems hardly tenable. The difference in date is, as she allows, not great, and the distinction of type is, to my mind, fundamental. 